\title{
BENTUK-BENTUK ABREVIASI DALAM BAHASA JAWA
}

\author{
Madda Yadal Musaa'adah \\ hanamadda@gmail.com \\ Ardian Yuliani Saputri \\ ardianyees@gmail.com \\ Universitas Sebelas Maret Surakarta
}

\begin{abstract}
This research was motivated by the use of abbreviations in communicating using Javanese. People prefer to use abreviations because they are shorter, faster, easier to remember, and easier to memorize. The purpose of this study is to classify the forms of abreviation, describe the patterns of the formation process, and describe the meanings of abreviations in the Javanese language, namely aferesis, syncope, and apocopy. Abreviation is a process of dating one or several parts of lexeme or a combination of lexemes that form a new form in the form of words. This study uses a qualitative-descriptive approach. The method of collecting data used proficient methods and referring methods. The data sources of this research were magazine articles in the form of written data of Javanese lexicons in the articles containing abreviations. In this study the abbreviations in the form of apheresis were found to be the highest number compared to abbreviations in the form of syncope and apocopy.
\end{abstract}

Keywords: abreviation; Javanese; apheresis; syncope; apocopy

\section{Pendahuluan}

Manusia membutuhkan bahasa untuk berkomunikasi dan berinteraksi sosial.Bahasa merupakan sarana utama yang digunakan oleh manusia dalam kehidupan sehari-hari. Bahasa merupakan sarana terpenting untuk menyampaikan informasi kepada orang lain baik itu ide, gagasan, ataupun maksud. Selama hidupnya, manusia akan terus menerus berbahasa karena manusia tidak lepas dari komunikasi baik komunikasi verbal maupun nonverbal. Komunikasi verbal adalah komunikasi yang disampaikan secara lisan. Sedangkan komunikasi nonverbal adalah komunkasi yang berupa tulisan.

Pemakaian bahasa di masyarakat lebih banyak menggunakan bahasa lisan daripada bahasa tulis.Bahasa lisan tersebut diwujudkan dalam bentuk rangkaian fonem yang berupa tuturan.Fonem merupakan suara yang menyebabkan sebuah kata memiliki perbedaan wujud dan makna. Fonem sendiri merupakan tahapan penting untuk menunjukkan bunyi bahasa sehingga bisa dipahami oleh lawan bicara.

Fonem merupakan bagian dari fonologi. Fonologi adalah salah satu kajian ilmu yang membahas mengenai suara atau bunyi. Salah satu kajian di dalam Fonologi adalah abreviasi. Abreviasi adalah suatu proses penanggalan satu atau beberapa bagian dari leksem atau kombinasi leksem yang membentuk bentuk baru yang berupa kata. Abreviasi disebut juga dengan pengurangan kata atau penyingkatan kata untuk kepraktisan dalam berkomunikasi. Dalam berkomunikasi, manusia sering menggunakan abreviasi dengan alasan lebih praktis dan cepat.Abreviasi seringkali ditemui baik dalam percakapan sehari-hari baik yang berbentuk tulisan maupun lisan. Dalam semua bahasa di dunia, penuturpenutur berusaha "menghemat" dalam pemakaian bahasa dan memperpendek tuturannya asalkan tidak menghambat komunikasi dan tidak bertentangan 
dengan budaya bahasa tersebut dipakai (Verhaar, 2001)

Menurut Kridalaksana

abreviasi adalah suatu proses penanggalan satu atau beberapa bagian dari leksem atau kombinasi leksem yang membentuk bentuk baru yang berupa kata. Proses abreviasi ini bisa dengan mengurangi kata satu atau beberapa bagian leksem di bagian awal, tengah, maupun di akhir. Meskipun terjadi pengurangan ataupun penanggalan beberapa bagian leksem, namun arti dan maknanya tetap sama dan tidak berubah. Di dalam bahasa Indonesia ada beberapa macam abreviasi. Merujuk teori Kridalaksana ada beberapa jenis abreviasi yang terdiri dari singkatan, akronim, kontraksi, penggalan, dan lambang huruf.

Selain itu, abreviasi dalam bahasa Indonesia muncul karena terdesak untuk berbahasa secara praktis dan cepat (Aprianto 2016). Di sisi lain, Wulandari (2014) berpendapat bahwa abreviasi merupakan proses pemendekan pada suatu kata yang dibagi menjadi lima jenis, yaitu singkatan, penggalan, akronim, kontraksi, dan lambang huruf.

Sementara itu, Ramlan (2001) mengungkapkan bahwa istilah lain untuk abreviasi adalah pemendekan sedangkan hasil prosesnya disebut kependekan. Selain itu, Chaer (2008) juga menyatakan bahwa abreviasi adalah proses penanggalan bagianbagian leksem atau gabungan leksem menjadi sebuah bentuk singkat, tetapi maknanya tetap sama. Jadi dapat disintesiskan bahwa abreviasi merupakan penghilangan satu atau beberapa bagian leksem sehingga membentuk kata baru yang tidak mengubah arti kata aslinya. Bentuk asal abreviasi menurut Ramlan (2009) dapat berupa kata, nama diri, maupun frasa yang kemudian dihilangkan, sedangkan proses abreviasi yaitu dengan melakukan penghilangan huruf dalam sebuah kata.
Bahasa Jawa juga mempunyai abreviasi. Di dalam bahasa Jawa abreviasi dikenal dengan istilah panyudaning swara yang bermakna 'pengurangan kata' atau plutan (Sasangka, 2011). Selanjutnya, Sasangka membagi abreviasi bahasa Jawa menjadi tiga, yaitu aferesis, sinkop, dan apokop.

Pertama, aferesis adalah pengurangan suara di bagian depan kata yang tidak mengakibatkan perubahan makna. Misalnya pada kata uwong yang bermakna 'manusia' mengalami proses pengurangan leksem pada bagian depan kata, sehingga menjadi kata wong yang juga bermakna 'manusia'.

Kedua, sinkop adalah pengurangan suara di bagian tengah kata yang tidak mengakibatkan perubahan makna. Misalnya pada kata sethithik yang bermakna 'sedikit' mengalami proses pengurangan leksem pada bagian tengah kata, sehingga menjadi kata sithik yang juga bermakna 'sedikit'.

Ketiga, apokop adalah pengurangan suara di bagian belakang kata yang tidak mengakibatkan perubahan makna. Misalnya pada kata tenanan yang bermakna 'sungguhan' mengalami proses pengurangan leksem pada bagian belakang kata, sehingga menjadi kata tenan yang juga bermakna 'sungguhan' (Sasangka, 2011).

Salah satu penelitian terkait abreviasi pernah dilakukan oleh Sudjalil (2018)yang berjudul, Tipologi Abreviasi dalam Surat Kabar Berbahasa Indonesia yang mengkaji tentang bentuk-bentuk abreviasi dalam surat kabar berbahasa Indonesia edisi Januari sampai dengan Maret 2016 pada kolom pendidikan yang ditemukan dalam bentuk akronim, kontraksi, penggalan, dan lambang huruf. Penelitian ini sama-sama mengkaji abreviasi tetapi berbeda objek kajian bahasa dan jenis-jenis teori abreviasi yang digunakan. 
Penelitian abreviasi juga pernah dilakukan oleh Yang (2011) dengan judul, Abbreviations in Maritime English yang mengkaji singkatan bahasa Inggris Maritim yang terus berkembang membawa aturan baru dalam membaca dan menulis, membuat kosa kata baru, penggunaan baru, yang mempengaruhi komunikasi dalam bidang pengiriman industri. Singkatan tersebut dapat menghemat waktu dalam menulis, membaca, dam berbicara. Penelitian ini fokus mengkaji tentang singkatan yang digunakan dalam dunia industri kemaritiman.

Penelitian abreviasi juga dilakukan oleh Lorna \& Carter (2012) yang berjudul, Greek or Not: The Use of Symbols and Abbreviations in Mathematics yang meneliti tentang penggunaan simbol dan singkatan dalam matematika yang memetakan kata-kata menjadi simbol. Simbol dalam pembelajaran matematika dapat memudahkan siswa memahami pembelajaran dan guru bisa mengatasi masalah dalam pembelajaran. Penggunaan abreviasi yang berupa simbol dan singkatan dapat meringankan beban linguistik bagi peserta didik.

Proses abreviasi memiliki tujuan tertentu salah satunya untuk menyingkat kata tanpa harus merusak arti kata pesan. Hal ini bisa dilihat dari beberapa tuturan orang Jawa yang banyak menyingkat kata dalam melakukan komunikasi.Penelitian mengenai abreviasi bahasa Jawa menarik untuk dikaji lebih lanjut. Teori Sasangka lebih lanjut akan digunakan dalam penelitian ini karena dari beberapa teori yang ada, teori Sasangka paling tepat digunakan untuk kajian abreviasi dalam bahasa Jawa. Oleh karena itu, pada tulisan ini akan dibahas mengenai abreviasi bahasa Jawa yang terdiri darijenis abreviasi, bentuk asal abreviasi, dan proses abreviasi.

\section{Metode Penelitian}

Penelitian ini menggunakan pendekatan deskriptif-kualitatif. Moleong (2004) mengungkapkan bahwa penelitian kualitatif bermaksud untuk memahami fenomena tentang apa yang dialami oleh subjek penelitian secara holistik dan dengan cara deskripsi dalam bentuk kata-kata dan bahasa pada suatu konteks khusus yang alamiah dan dengan memanfaatkan berbagai metode alamiah.

Penelitian ini meneliti tentang bentuk abreviasi dalam bahasa Jawa yang terdiri dari aferesis, sinkop, dan apokop. Penelitian ini mendiskripsikan jenis, bentuk asal, dan proses abreviasi bahasa Jawa.

Metode pengumpulan data dalam penelitian ini adalah dengan menggunakan metode cakap dan metode simak. Metode cakap dengan menggunakan teknik cakap semuka dan teknik lanjutan teknik catat. Sedangkan metode simak menggunakan teknik sadap dan teknik catat. Sumber data menurut Suharsimi (2010, 172) adalah subjek dari mana data diperoleh. Sumber data penelitian ini adalah artikel dari majalah berbahasa Jawa Panjebar Semangat edisi 3 Oktober 2015. Sementara itu, data yang digunakan dalam penelitian ini adalah data tulis yang berupa leksikon bahasa Jawa yang mengandung abreviasi. Metode analisis data yang digunakan pada penelitian ini adalah metode distribusional, yaitu metode analisis yang unsur penentunya adalah dari bahasa yang bersangkutan itu sendiri.

\section{Pembahasan}

Abreviasi adalah penghilangan satu atau beberapa bagian leksem sehingga membentuk kata baru yang tidak mengubah arti kata aslinya. Bentuk abreviasi yang dimaksud dalam penelitian ini dibedakan menjadi tiga yaitu, aferesis, sinkop, dan apokop.Hasil penelitian ini berupa kata-kata bahasa Jawa yang 
mengalami abreviasi yang terdiri aferesis, sinkop, dan apokop. Pada penelitian ini data abreviasi diperoleh dari Majalah Panjebar Semangat edisi 3 Oktober 2015. Sebagaimana dinyatakan Sasangka (2011), abreviasi bahasa Jawa terbagi menjadi tiga, yaitu aferesis, sinkop, dan apokop.

\section{Aferesis}

Aferesis adalah pengurangan bagian dari leksem yang berada di bagian depan kata. Meskipun berubah leksemnya namun makna atau arti kata tersebut tidak berubah. Proses abreviasi dalam bentuk aferesis yang ditemukan dalam penelitian ini di anataranya: ora-ra, uwis-wis, pancenncen, usah-sah, durung-rung, akonkon, kaping-ping, namung-mung, banjur-njur, bocah-cah, uwong-wong, dan thole-le.

(1) ora - ra (tidak)

Aku ra pinter golek ngunu kuwi (Aku tidak pandai mencari seperti itu).

Kata ra dalam kalimat tuturan diatas berasal dari kata 'ora' yang mengalami perubahan leksem berupa penghilangan satu suku kata di bagian depan, yakni o-. Kata ra dan ora memiliki makna yang sama, yang artinya adalah 'tidak'.

(2) uwis - wis (sudah)

Wis tak jupuk (Sudah saya ambil).

Kata wis dalam kalimat tuturan diatas berasal dari kata uwis yang juga mengalami perubahan leksem berupa penghilangan satu suku kata di bagian depan, yakni $u$-. Wis dan uwis memiliki makna yang sama, yang artinya adalah 'sudah'.

(3) pancen - ncen (memang)

Ncen kok kowe kuwi (Memang kok kamu itu).

Kata ncen dalam kalimat tuturan diatas berasal dari kata pancen yang mengalami perubahan leksem berupa penghilangan satu suku kata di bagian depan, yakni pan-.
Ncen dan pancen memiliki makna yang sama, yang artinya adalah 'memang'.

(4) $u s a h$ - sah (perlu)

Ora sah diijoli (Tidak perlu diganti).

Kata sah dalam kalimat tuturan diatas berasal dari kata usah yang juga mengalami perubahan leksem berupa penghilangan satu suku kata di bagian depan, yakni $u$-. Sah dan usah memiliki makna yang sama, yang artinya adalah 'perlu'.

(5) durung - rung (belum)

Materine rung rampung (Materinya belum selesai).

Kata rung dalam kalimat tuturan diatas berasal dari kata durung yang mengalami perubahan leksem berupa satu suku kata di bagian depan, yakni $d u$-. rung dan durung memiliki makna yang sama, yang artinya adalah 'belum'.

(6) akon - kon (suruh)

Sesuk tak kon mlebu (Besok saya suruh untuk masuk).

Kata kon dalam kalimat tuturan diatas berasal dari kata akon yang juga mengalami perubahan leksem berupa penghilangan satu suku kata di bagian depan, yakni $a$-. Kon dan akon memiliki makna yang sama, yang artinya adalah 'suruh'.

(7) kaping - ping (kali)

Berarti aku ping telu njagane (Berarti aku tiga kali menjaganya).

Kata ping dalam kalimat tuturan diatas berasal dari kata kaping yang juga mengalami perubahan leksem berupa penghilangan satu suku kata di bagian depan, yakni ka-. Ping dan kaping memiliki makna yang sama, yang artinya adalah 'kali' yang menunjukkan frekuensi kejadian. 
(8) namung - mung (hanya)

Ana sing mung jagongan karo ngobrol (Ada yang hanya duduk sambil ngobrol).

Kata mung dalam kalimat diatas berasal dari kata namung yang juga mengalami perubahan leksem berupa penghilangan satu suku kata di bagian depan, yakni na-. Kata mung dan namungmemiliki makna yang sama, yang artinya adalah 'hanya'.

(9) banjur - njur (kemudian)

Sekar arep dadi mantune, njur rumangsa sungkan arep dhawuhdhawuh (Sekar ingin jadi menantunya, kemudian merasa sungkan ingin meyuruh-nyuruh).

Kata njur dalam kalimat diatas berasal dari kata banjur yang juga mengalami perubahan leksem berupa penghilangan satu suku kata di bagian depan, yakni ban-. Kata njur dan banjur memiliki makna yang sama, yang artinya adalah 'kemudian'.

(10) bocah - cah (anak); uwong - wong (manusia)

Ooo, endah-endah cah ndesa anake wong nggombal pitu likur (Ooo, jelas-jelas anak desa anaknya orang penggoda dua puluh tujuh).

Terdapat dua kata yang mengalami abreviasi pada kalimat di atas. Pertama, kata cah dalam kalimat diatas berasal dari kata bocah yang juga mengalami perubahan leksem berupa penghilangan satu suku kata di bagian depan, yakni bo-. Kata cah dan bocah memiliki makna yang sama, yang artinya adalah 'anak'. Kedua, kata wong dalam kalimat diatas berasal dari kata uwong yang juga mengalami perubahan leksem berupa penghilangan satu suku kata di bagian depan, yakni $u$-. Kata wong dan uwongmemiliki makna yang sama, yaitu 'manusia'.
(11) thole - le (sapaan untuk anak lakilaki)

Ngene ya, Le..., sapa jenengmu mau?(Begini ya Nak ..., siapa namamu tadi?)

Kata le dalam kalimat diatas berasal dari kata tole yang juga mengalami perubahan leksem berupa penghilangan satu suku kata di bagian depan, yakni tho-. Kata thole dan le memiliki makna sama, yang artinya adalah aapaan untuk anak laki-laki.

Berdasarkan temuan di atas, dapat disimpulkan bahwa bentuk kata abreviasi aferesis berasal dari katakata yang terdiri dari dua suku kata (atau lebih) yang dihilangkan suku kata bagian depannya.

\section{Sinkop}

Sinkop adalah pengurangan bagian dari leksem yang letaknya di tengah kata.Meskipun terjadi pengurangan di tengah kata, makna atau arti kata tidak berubah.Abreviasi berbentuk sinkop yang ditemukan dalam penelitian ini di antaranya kuwi-kui, temenan-tenan, nanging-ning, rumiyinriyin, nyai-nyi.

(1) kuwi - kui (itu)

Nggolek ngunu kui (Mencari seperti itu).

Kata kui dalam kalimat diatas berasal dari kata kuwi yang mengalami perubahan leksem berupa penghilangan satu fonem /w/ di tengah kata. Kata kui dan kuwi memiliki makna yang sama, yaitu 'itu'.

(2) nanging - ning (tetapi)

Ning kowe rak kudu nulak gaweyan sing ditawakake Pak Basir (Tetapi kamu tidak harus menolak pekerjaan yang ditawari Pak Basir).

Kata ning dalam kalimat diatas berasal dari kata nanging yang mengalami perubahan leksem berupa penghilangan dua fonem /a/ dan $/ \mathrm{y} /$ di tengah kata. Kata ning 
dan nanging memiliki makna sama, yang artinya adalah 'tetapi'.

(3) rumiyin - riyin (dulu)

Katuran pinarak, kula tak adus riyin (Silahkan masuk, saya mandi dulu)

Kata riyin dalam kalimat diatas berasal dari kata rumiyin yang juga mengalami perubahan leksem berupa penghilangan dua fonem /u/ dan $/ \mathrm{m} /$ di tengah kata. Kata riyindan rumiyin memiliki makna yang sama, yang artinya adalah 'dulu'.

(4) nyai - nyi (ibu/bu)

Nanging apa, nyi?(Tapi apa, Bu?)

Kata nyi dalam kalimat diatas berasal dari kata nyai yang juga mengalami perubahan leksem berupa penghilangan satu fonem di tengah kata, yakni fonem /a/. Kata nyi dan nyai memiliki makna sama, yang artinya adalah 'bu' atau 'ibu' (panggilan kepada seorang wanita yang merupakan istri orang yang berilmu).

Berdasarkan contoh-contoh di atas dapat disimpulkan bahwa abreviasi sinkop dalam bahasa Jawa berupa penghilangan satu atau dua fonem pada bagian tengah suatu kata.

\section{Apokop}

Apokop adalah pengurangan suku kata bagian di bagian belakang suatu kata.Meskipun terjadi pengurangan suku kata, makna atau arti kata tersebut tidak berubah. Peristiwa abreviasi melalui apokop yang ditemukan dalam penelitian ini di antaranya adalah tenanan-tenan, mbakyu-mbak, dan kangmas-kang.

(1) tenanan - tenan(benar)

Tenan ya, beb (Beneran ya, beb).

Kata tenan dalam kalimat diatas berasal dari kata tenanan yang mengalami perubahan leksem berupa penghilangan dua fonem terakhir, yakni /a/ dan /n/ . Kata tenan dan tenanan memiliki makna yang sama, yang artinya adalah 'sungguh-sungguh'.

(2) mbakyu -mbak (kakak perempuan)

Mbak Mira kowe lagi ngapa? (Mbak Mira kamu baru apa?)

Kata mbak dalam kalimat tuturan diatas berasal dari kata mbakyu yang juga mengalami perubahan leksem berupa penghilangan satu suku kata $-y u$ di belakang. Kata mbak dan mbakyu memiliki makna yang sama, yang artinya adalah 'kakak perempuan'.

(3) kangmas - kang (kakak laki-laki)

Bener Kang, bolane sing mentas mocap iku mau(Benar Kak, ternyata yang naik panggung itu tadi).

Kata kang dalam kalimat diatas berasal dari kata kangmas yang juga mengalami perubahan leksem berupa penghilangan satu suku kata di belakang sebuah kata. Kata kang dan kangmas memiliki makna sama, yang artinya adalah sapaan untuk saudara laki-laki yang lebih tua.

Dari sini dapat disimpulkan bahwa bagian yang dihilangkan pada abreviasi bentuk apokop adalah suku kata paling akhir.

Berdasarkan berbagai contoh abreviasi di atas secara umum dapat disimpulkan bahwa bentuk abreviasi kata dalam bahasa Jawa bisa berupa penghilangan suku kata atau fonem yang posisinya berada di depan, tengah ataupun belakang.

\section{KESIMPULAN}

Dari pembahasan di atas, dapat disimpulkan bahwa bentuk abreviasi dalam tuturan bahasa Jawa dan media tulis yang ditemukan meliputi bentuk aferesis, sinkop, dan apokop. Abreviasi dalam bentuk aferesis ditemukan jumlahnya paling banyak dibandingkan abreviasi yang berbentuk sinkop dan apokop. Bentuk asal abreviasi dalam bahasa Jawa yang ditemukan pada penelitian ini hanya berupa kata. 
Proses abreviasi bahasa Jawa dilakukan dengan dengan menghilangkan suku kata atau fonem baik di depan kata, tengah kata, maupun di akhir kata.

Penelitian ini diharapkan memberikan kontribusi terhadap kajian fonologi terutama dalam abreviasi bahasa Jawa. Selain itu, diharapkan dengan adanya penelitian ini, dapat membantu perkembangan bahasa Indonesia juga bahasa Jawa, sehingga lembaga bahasa dapat mempertimbangkan dan menjadikan penelitian-penelitian abreviasi menjadi suatu hal yang berguna untuk kedepannya nanti. Dari penelitian yang telah dilakukan tentang abreviasi dalam bahasa Jawa ini, maka peneliti menyarankan untuk peneliti selanjutnya untuk melakukan penelitian abreviasi dengan melibatkan payung penelitian sosiolingusitik atau semantik dalam kajiannya agar dapat mengungkap fenomena abreviasi lebih mendalam dan dapat dihubungkan dengan fenomena dimasyarakat.

\section{DAfTar Pustaka}

Aprianto, Andika. 2016. Abreviasi Bahasa Indonesia Dalam Harian Rakyat Kalbar.Pontianak: FKIP Universitas Tanjungpura

Chaer, Abdul. 2008. Morfologi Bahasa Indonesia: Pendekatan Proses. Jakarta: Pusat Bahasa dan Balai Pustaka

Kridalaksana, Harimurti. 2007. Pembentukan Kata dalam Bahasa
Indonesia. Jakarta: PT Gramedia Pustaka Utama.

Moleong, Lexy J. 2007. Metodologi Penelitian Kualitatif. Bandung: PT Remaja Rosdakarya

Quinell, Lorna \& Merilyn Carter. 2012. "Greek or Not: The Use of Symbols and Abbreviations in Mathematics". The Australian Association of Mathematics Teachers (AAMT) Inc., 68 (2)

Ramlan, M. 2001. Ilmu Bahasa Indonesia: Sintaksis. Yogyakarta: UB Karyono.

Ramlan, M. 2009. Morfologi: Suatu Tinjauan Deskriptif. Yogyakarta: CV Karyono.

Sasangka, Sry STW. 2011. Paramasastra Gagrag Anyar Basa Jawa. Jakarta: Yayasan Paramalingua

Sudjalil. 2018. "Tipologi Abreviasi dalam Surat Kabar Berbahasa Indonesia". Jurnal Keilmuan Bahasa, Sastra, dan Pengajarannya, 4 (1): 69-82

Suharsimi, Arikunto. 2010. Prosedur Penelitian: Suatu Pendekatan Praktik. Jakarta: Rineka Cipta

Verhaar, JWM. 2001. Asas-asas Linguistik Umum. Yogyakarta: Gadjah Mada University Press.

Wulandari, Retno Eko. 2014. Penggunaan Abreviasi Dalam Bahasa Sunda(Kajian Morfosemantis). Bandung: FPBS UPI

Yang, Zhirong. 2011."Abbreviations in Maritime English". Canadian Center of Science and Education 4 (1)

\section{UCAPAN TERIMA KASIH}

Artikel ini ditulis di bawah bimbingan Prof. Dr. Sumarlam, MS dari Universitas Sebelas Maret Surakarta. 